Review article

\title{
Spatial Imaginings in the Age of Colonial Cartographic Reason: Maps, Landscapes, Travelogues in Britain and India by Nilanjana Mukherjee
}

London and New York: Routledge, 2021, xiii+300 pp., \$160.00 (hardbound), ISBN

9780367749583

Sutapa Dutta

Gargi College, University of Delhi. Email: sdutta.eng@gmail.com

Nilanjana Mukherjee's book looks at construction of space, leading from imaginative to concrete contours, within the context of the British imperial enterprise in India. Fundamental to her argument is that colonial definitions of sovereignty were defined in terms of control over space and not just over people, and hence it was first necessary to map the space and inscribe symbols into it. In the latter half of the eighteenth century, imperialism and colonization were complex phenomena that involved new and imminent strategies of nation building. No other period of British history, as Linda Colley has noted, has seen such a conscious attempt to construct a national state and national identity (Colley 1992). Although the physical occupation of India by the British East India Company could be said to have begun with the battle of Plassey (1757), nevertheless the process of conquest through mediation of symbolic forms indicate the time and manner in which the 'conquest' was conscripted.

Mukherjee's book is neatly structured into three parts around chapters dedicated to each of what she has identified as three approaches to spatial mapping, namely, maps, landscape paintings and travel writings. The first chapters in each of these sections discuss spatial matrices as constituted by the West, especially by the British. The second chapters in each section then go on to expand on such spatial representations specifically in the context of India. All three parts are logically interconnected, as maps and paintings had strong connections with travel and recounting. Building on Henri Lefebvre's 'spatial practice', the author locates the work on representations of space as it is imagined, conceived and formulated (Lefebvre 1991). Part One deals with colonial cartographic endeavours and practices in constructing the metropolis, the colony and the empire in general. In the first chapter she makes detailed study of cartographic and hydrographic methods of mapping in the West which emerged as important practices to ultimately control the visual imagination of the bound and fortified space of a nation. The second chapter focuses on the 'scientific' and 'modern' method of mapping which began with the advent of the British in India. In pre-colonial India a geophysical perception of the ecumene always existed in the general consciousness. This, as Mukherjee mentions, was mainly an abstract idea manifested through

This Open Access article is published under a Creative Commons Attribution Non-Commercial 4.0 International License (http://creativecommons.org/licenses/by-nc/4.0/), which permits non-commercial re-use, distribution, and reproduction in any medium, provided the original work is properly cited. For citation use the DOI. For commercial re-use, please contact editor@rupkatha.com. 
signs, symbols, stories, songs, myths, performances, and practices. Till the mid-eighteenth century, geographical mapping in India was largely based on information gathered by travellers and missionaries. Early colonial discourses on India can be seen as imaginary constructs willed by the colonial agent straining to understand the strange and unfamiliar land. India was therefore presented in ways that would appeal to the curious informed readers back in England. From the 1770 's as the British took a more proactive role in administration, the key to how Britain could ensure better 'control' lay in the detailed study of India. There began an intense cataloguing and categorising of languages, races and tribes in India to secure a better understanding of the unchartered civilization they had to administer. To use Bernard Cohn's terminology, such 'investigative modalities' were 'official' ways of producing knowledge (Cohn 1996). It enabled a rhetoric of not only projecting the Other but also a construction of self-image, both crucial for power and control. The introduction of cartography, of mapping and surveying, was then essentially a scientific Western practice that was brought by the early European travellers and Company officials. Western understanding of the rest of the world was characterised by a juxtaposition of romanticisation of the Other along with an attempt at 'scientific' understanding of eastern civilisation. Taking up the cases of James Rennell and William Lambton, Mukherjee discusses the discourse of colonial surveying and mapping which heralded a new age of cartographic practices. What had hitherto remained an abstract, conceptual geography now became a definitive, objective compilation of geographical data, comprising of maps, atlases and survey reports based on the very innovative method of 'Trigonometrical Survey'. These, as Ian Barrow has pointed out, was influential in forming opinions and perspectives, and projected a positive image, one that legitimised the British possession of an area that was no longer unfamiliar (Barrow 2003).

Part Two of the book invites a debate on the constructed nature of spaces through a discussion on landscape paintings which was according to Mukherjee, a 'specifically European genre born of a cartographic impulse'. The first chapter in this section looks at the cultural production of landscapes in Great Britain, and how the expansive vision of the landscape moved from the city to the countryside and subsequently to the peripheries, very similar in its sweep and scope to the encompassing cartographic gaze. In England, landscape paintings, descriptions of landscapes in poetry, or as stage sceneries helped create the illusion of a pastoral golden age. What was commonly seen as artistic representations was to soon be seen as objective and factual with eighteenth-century naturalism and spatiality entering the academic discourse of geology and geography. The book throws light on landscape artists like John Constable, J.M.W. Turner, Robert Dawson, and others who were influenced by the visual models of the map and other scientific and meteorological texts and diagrams. Their paintings reflected a three dimensional depiction of geo-physical structures, giving them a trigonometrical representation. Such aesthetic pictures of the land were then suffused with a 'scientific', analytical gaze, soon to be commended as the "British National Style". Similarly, the paintings of the uncle-nephew duo, Thomas Daniell and William Daniell illuminate the growing trend to capture the landscape as a spectacle, albeit with artistic liberties. The next chapter in this section is a study of how India was visualised in the landscape art as practised by the British in India. A detailed discussion of the works of two wellknown British painters in India, George Chinnery and Charles D'Oyly, indicate how India became a valuable exhibit as an imperial spectacle. D'Oyly, a prolific painter, had an influential role to play 
in the development of what became known as the "Company School". Understandably then, native bodies, their rituals, customs and ways of life, like sati, extravagant marriage ceremonies and imposing processions were the subjects of fascination for painters like D'Oyly and William Hodges who were very often trying to attach the aura of authenticity to the imagery of colonial fantasy. Depiction of the native way of life were obviously for the gratification of a general public back home who were already aware of a world outside their own island. It was as Mukherjee puts it 'a whole panoply of shows' to amuse and educate the home audience, a veritable substitute of the role of the print and electronic media of today.

The first chapter of Part Three of the book, following the earlier structural pattern, looks at English travel narratives which primarily aimed to fashion English society and space. Such literary narratives thus present a 'literary geography', a complex intersection between cartography and literature which constructs spaces, shapes boundaries and forges distinct units. Citing instances beginning from early sixteenth century, the book explores travel writings as an eclectic genre for religious pilgrimage, exploration, trade, missionary activity, scientific discoveries, and personal development. Early Western travelogues, memoirs and journals provided a discursive space in the active making of a global geography upon which British imperialism was to be founded. This was to build an encyclopaedic collection of all kinds of knowledge thought to be beneficial for England in its relationship with other nations. Travel writing became an important site for constructing the idea of Britishness and in ushering the dominance of Britain as a world power. At the same time such writings bring out the complex layers of subject formation within the larger colonial discourse. Britain's relationship with the conceptual Other was posited in carefully constructed literary geography that implicitly encouraged a comparison of binaries. The next chapter considers some of the travel literature produced by colonial personnel who had been to India on various missions during the period 1750-1850, in an attempt to recast their own home-grown spatial notions in seeking to articulate from this basis, its territorial bounds. Selecting the writings of some representative colonial travellers in India, a painter, a missionary, an administrative retinue and a botanist, Mukherjee elucidates how the colonial designs of expansion was transcribed. Their writings reveal ways in which map literacy and scientific knowledge were used for the service of religion and deeper scientific investigation of the geographical, antiquarian and historical relations of the foreign space.

Mukherjee's overview of map making and cartographic practices in British India is located within earlier arguments and scholarship in this area, most notably Matthew H. Edney's Mapping an Empire, Ian J. Barrow's Making History, Drawing Territory and Manu Goswami's Producing India (Barrow 2003; Edney 1997). Similar arguments about the British will to know, to document and to classify, and how such strategies enabled colonial rule while simultaneously being enabled have been discussed by scholars such as Bernard Cohn, Nicholas Dirks, Ronald Inden, and C. A. Bayly, to name but a few (Bayly 1996: Cohn 1996; Dirks 2001; Inden 1990). What Mukherjee does is to extend this work in interesting and novel directions by presenting a broader canvas and multiple mediums to understand the representation of space. The overlapping of the ocular and the textual, the scientific and the artistic, produces a cohesive sense of colonial spatialisation. The book closes with a postscript that emphasises the continuing importance and use of maps in our modern daily lives as we are increasingly dependent on google maps and GPS to locate our positions on the 
globe. The human-digital technology has merely transformed the organising of information into a new nexus of technology, politics and power.

There is very little to cavil in this excellent work. However, I feel the spatial imagining of the colonial space cannot be complete without some more light on the contribution of transport infrastructure laid out by the colonial administration to map the country. The panoptic view of the land as depicted in the paintings and travel writings was concretised by a consolidated overview of extensive land and water routes. A wide-spread transport infrastructure facilitated movement of goods and men and collection of taxes, bringing the country under an efficient system of administration. The rebellion of 1857 necessitated a more rigorous political and military control, and there was an unprecedented urgency for a more forceful spatial planning The introduction of a massive railway grid, one of the largest single investment taken by the British anywhere, was the most distinct thrust in this direction. Mukherjee makes a passing reference to the impact of improved transport infrastructures which resulted in compressions of geography and appropriation of peripheries, creating for the first time the possibility of understanding the country as a whole. The section on travel writings would have greatly benefited if it had also looked at the extraordinary burgeoning of operated travel organisations and the resultant railway timetables, travel almanacs and guidebooks that came up to introduce prospective travellers to their land of travel. These were no less important than a cartographic mapping of the land, and helped to restructure the imperial project of commodifying places for consumption. Again, the third part of the book where Mukherjee looks at the works of Bishop Heber and the botanist, Joseph Dalton Hooker to assert how Christian evangelism took recourse to science as an effective means to rationalise and modernise the native mind, curiously omits to mention William Carey's contribution to unite the religious, the aesthetic and the scientific. What Hooker and his father did for the Kew Gardens in London was paralleled by the Serampore Baptist missionary William Carey and William Roxburgh's contribution to botany and to the Botanical Gardens in Calcutta. Britain's promotion of specialised interests in horticulture and botany, which then was simultaneously echoed in the colonies, was greatly enriched by Carey and Roxburgh's monumental work on collecting and cataloguing the flora of India.

What is further debatable is the author's postulation that colonial mappings signal a distinctly modern approach based on a rupture between the precolonial past and a modern colonial present. There is a danger in treating colonial knowledge systems as fundamentally and even irrevocably different from their precolonial predecessors. As argued in recent works by Kapil Raj and C. A. Bayly, the highly paternalistic attitude of the British officials was to give way to a hybridity which drew upon Indian expertise (Bayly 1996; Raj 2006). It is becoming increasingly clear that many precolonial Indian states had well-developed knowledge systems of their own. In her introduction to the book, Mukherjee mentions different scholarly trajectories taken to understand the influence of Sanskritic and Mughal Islamic traditions of mathematical and astral practices which gave rise to hybrid spatio-temporal configurations. However, it would have been interesting to see in her work how modern geopolitical realities were impacted by indigenous sources of cartographic traditions and knowledge of mapping. Since all forms of representations are artifices, it is important to understand what was included and figured, and what got erased and distorted. Nonetheless, Mukherjee's work eloquently opens up a fascinating vista of possible ways to comprehend the spatial imaginings of the empire that underscored British claims of colonial 
Raj, Kapil. 2006. Relocating Modern Science: Circulation and the Construction of Knowledge in South Asia and Europe, seventeenth to nineteenth centuries. New Delhi: Permanent Black.

legitimacy. Incorporating a rich array of primary and secondary sources, as well as images, this book is an engaging read and worth procuring for an understanding of the history of colonial cartography in India.

\section{References}

Barrow, Ian J. 2003. Making History, Drawing Territory: British Mapping in India, 1756-1905. Oxford: Oxford University Press.

Bayly, C. A. 1996. Empire and Information: Intelligence Gathering and Social Communication in India, 1780-1870. Cambridge: Cambridge University Press.

Cohn, Bernard S. Colonialism and its Forms of Knowledge: The British in India (Princeton: Princeton University Press, 1996).

Colley, Linda. 1992. Britons: Forging the Nation, 1707-1837. New Haven: Yale University Press.

Dirks, Nicholas. 2001. Castes of Mind: Colonialism and the Making of Modern India. Princeton: Princeton University Press.

Edney, Matthew H. 1997. Mapping an Empire: The Geographical Construction of British India, 1765-1843. Chicago: The University of Chicago Press.

Inden, Ronald. 1990. Imagining India. Oxford: Basil Blackwell.

Lefebvre, Henri. 1991. The Production of Space. Tr. by Donald Nicholson-Smith. Oxford: Blackwell Publishing.

Raj, Kapil. 2006. Relocating Modern Science: Circulation and the Construction of Knowledge in South Asia and Europe, seventeenth to nineteenth centuries. New Delhi: Permanent Black.

Dr. Sutapa Dutta is in the Department of English at Gargi College, University of Delhi. Her research interests and publications are focused on eighteenth and nineteenth century writings, and cover gender, education and identity politics in colonial India, especially the work of missionary women and western women travellers to India. She is a Fellow at the Royal Historical Society of London, and a former Fellow of the Indian Institute of Advanced Study (IIAS), Shimla (2018-2020). She is the author of British Women Missionaries in Bengal, 1793-1861 (2017) and Disciplined Subjects: Schooling in Colonial Bengal (2021). 